\title{
Effect of ultra-thin polymer membrane electrolytes on dye- sensitized solar cells
}

\author{
Hongsheng Yang, Oliver A. Ileperuma, Masaru Shimomura, Kenji Murakami* \\ Research Institute of Electronics, Shizuoka Unversity, 3-5-1 Johoku, Naka, Hamamatsu, \\ 432-8011, Japan
}

\begin{abstract}
In-situ ultra-thin porous poly(vinylidene fluoride-co-hexafluoropropylene) $\mathrm{P}(\mathrm{VDF}-\mathrm{HFP})$ membranes were prepared by a phase inversion method on $\mathrm{TiO}_{2}$ electrodes coated with $\mathrm{Ru}$ N-719 dye. These membranes were then soaked in the organic liquid electrolyte to form the in-situ ultra-thin porous $\mathrm{P}(\mathrm{VDF}-\mathrm{HFP})$ membrane electrolytes. Dye-sensitized solar cell (DSC) using the membrane electrolyte exhibited an open circuit voltage $\left(\mathrm{V}_{\mathrm{oc}}\right)$ of $0.751 \mathrm{~V}$, a short circuit current $\left(\mathrm{J}_{\mathrm{sc}}\right)$ of $16.260 \mathrm{~mA} \mathrm{~cm} \mathrm{c}^{-2}$ and a fill factor (FF) of 0.684 under an incident light intensity of $1000 \mathrm{~W} \mathrm{~m}^{-2}$ yielding an energy conversion efficiency $(\eta)$ of $8.35 \%$. The $V_{\text {oc }}$, FF and $\eta$ of the solar cell using the membrane electrolyte increased by about $5.8 \%, 2.2 \%$ and $5.7 \%$, respectively, when compared with the corresponding values of a cell using liquid electrolyte. However, the $\mathrm{J}_{\mathrm{sc}}$ decreased by about $2.1 \%$.
\end{abstract}

Keywords: Dye-sensitized solar cells (DSCs); in-situ ultra-thin porous polymer

*Corresponding author. Tel.: +81 53478 1329; fax: +81 534781329.

E-mail address: rskmura@ipc.shizuoka.ac.jp 
membrane; polymer membrane electrolyte; P(VDF-HFP); quasi-solid DSCs.

\section{Introduction}

Photovoltaic technology utilizing solar energy has received considerable attention as one of the environmentally sustainable energy technologies. The dye-sensitized solar cells (DSCs) provide a promising alternative to conventional $\mathrm{p}-\mathrm{n}$ junction photovoltaic devices because of their relatively high efficiency, simple fabrication process and low production cost [1-3]. The highest efficiency of DSC reported is $11.18 \%$ under AM 1.5 $\left(1000 \mathrm{~W} \mathrm{~m}^{-2}\right)$ when used in conjunction with a liquid electrolyte containing the $\mathrm{I}^{-} / \mathrm{I}_{3}^{-}$ redox couple [4]. However, the liquid electrolyte containing $\mathrm{I}^{-} / \mathrm{I}_{3}{ }^{-}$redox couple may limit device stability due to a loss of the iodine by sublimation and the liquid electrolyte may leak or evaporate when the cell is imperfectly sealed. In addition, a permeation of water or oxygen molecules and their reaction with the electrolyte may worsen the cell performance. Liquid electrolyte also makes the manufacture of multi-cell modules difficult [5-7].

Several approaches have been used to overcome such problems by replacing of the volatile liquid electrolyte with a solid-state hole conductor, quasi solid-state gel electrolyte or ionic liquid electrolyte (IL) [5-12]. However, the efficiencies of DSCs with these alternative media are usually lower than that of DSCs with organic liquid electrolyte, which is attributed to a higher ionic transport resistance of such media compared with that of liquid electrolyte. Thus, reducing the ionic transport resistance is a key point to improve the efficiency of DSCs. Recently, DSCs with $\mathrm{P}(\mathrm{VDF}-\mathrm{HFP}) / \mathrm{TiO}_{2}$ 
composite electrolyte showed a higher efficiency than that of DSCs with liquid electrolytes, which is due to a low ionic transport resistance and scattering effect [1314]. On the other side, reduce the thickness of electrolyte can also reduce the ionic transport resistance. Although many gel polymer electrolytes have been reported as alternative electrolytes for DSCs, to our knowledge the use of ultra-thin porous polymer membrane electrolytes has not been reported.

$\mathrm{P}(\mathrm{VDF}-\mathrm{HFP})$ is a copolymer consisting of crystalline vinylidene fluoride (VDF) and amorphous hexafluoropropylene (HFP) units. It has been widely used as the polymer matrix material in the polymer electrolyte of lithium rechargeable battery due to its excellent chemical stability and mechanical properties [15-16]. The application of a thin film of poly(methylsiloxane) on exposed $\mathrm{TiO}_{2}$ surface to passivate the $\mathrm{TiO}_{2} /$ solution interface and thereby reduce an interfacial charge recombination reactions with a ferrocene/ferrocenium redox couple has been reported [17]. Similarly the traps which act as charge recombination centers of the $\mathrm{TiO}_{2}$ electrode can be covered by the $\mathrm{P}(\mathrm{VDF}-\mathrm{HFP})$ chains, which is beneficial to reduce the charge recombination rate and improve the efficiency. This paper describes a development of in-situ ultra-thin porous $\mathrm{P}(\mathrm{VDF}-\mathrm{HFP})$ membrane electrolytes and a comparison of its role in the DSC performances with that of the standard liquid electrolyte.

\section{Experimental section}

2.1. Preparation of dye-sensitized $\mathrm{TiO}_{2}$ electrode 
$\mathrm{TiO}_{2}$ electrodes were prepared by a spray pyrolysis deposition technique using a mixture of two $\mathrm{TiO}_{2}$ colloids at $150{ }^{\circ} \mathrm{C}$ [18]. The mixed $\mathrm{TiO}_{2}$ colloid solution contained $\mathrm{TiO}_{2}$ colloid (TAYCA TKC-302, $25 \mathrm{ml}$ ), acetic acid $(5.5 \mathrm{ml}), \mathrm{TiO}_{2}$ powder (Degussa $\mathrm{P} 25,0.5 \mathrm{~g}$ ) and a non-ionic surfactant (Triton-X-100, 5 drops). The plates were heated at $500{ }^{\circ} \mathrm{C}$ for 30 minutes in air and then soaked in a $5 \times 10^{-4} \mathrm{M}$ solution of the Ru N-719 dye, cis-bis(thiocyanato)-N-bis(4,4'-tetrabutylammonium' hydrogen dicarboxylato-2,2'bipyridine) ruthenium(II) in tert-butyl alcohol / acetonitrile $(1: 1, \mathrm{v} / \mathrm{v})$ mixed solution for $12 \mathrm{~h}$.

\subsection{Preparation of the electrolyte}

$\mathrm{P}(\mathrm{VDF}-\mathrm{HFP})$ copolymer (Aldrich) was dissolved in acetone and ethanol (4:1, v/v) mixed solvent and its weight percentage was $0.4 \%$. The in-situ ultra-thin porous $\mathrm{P}(\mathrm{VDF}-\mathrm{HFP})$ membranes were prepared by using (membrane I) one drop, (membrane II) two drops or (membrane III) four drops of P(VDF-HFP) acetone/ethanol solution on the $\mathrm{TiO}_{2}$ electrodes coated with $\mathrm{Ru}$ N-719 dye. The $\mathrm{TiO}_{2}$ electrode with $\mathrm{P}(\mathrm{VDF}-\mathrm{HFP})$ membrane was kept in a vacuum at room temperature for $0.5 \mathrm{~h}$ and then soaked in the liquid electrolyte (0.1 M LiI, 0.05 $\mathrm{M} \mathrm{I}_{2}, 0.5 \mathrm{M}$ tert-butyl pyridine, 0.6 M 1,2-dimethyl, 3propylimidazolium iodide in acetonitrile) to form the in-situ ultra-thin porous $\mathrm{P}(\mathrm{VDF}-\mathrm{HFP})$ membrane electrolyte.

\subsection{Fabrication of the DSCs}


The $\mathrm{TiO}_{2}$ electrode with $\mathrm{P}(\mathrm{VDF}-\mathrm{HFP})$ membrane electrolyte was covered with a $\mathrm{Pt}$ sputtered counter electrode to complete the cell. An identical solar cell with the organic liquid electrolyte was also assembled for comparison purposes.

\subsection{Measurements}

For the scanning electron microscopy (SEM) experiment, $\mathrm{TiO}_{2}$ electrode was sputter coated with gold for 40 seconds at a current of 7 mA. A SEM (JEOL 6320F) instrument with an accelerating voltage of $15 \mathrm{kV}$ was employed to examine the $\mathrm{TiO}_{2}$ electrode surface, and in-situ ultra-thin porous $\mathrm{P}(\mathrm{VDF}-\mathrm{HFP})$ membranes were examined without gold coating with an accelerating voltage of $2 \mathrm{kV}$. Because the surface of $\mathrm{TiO}_{2}$ electrode is rough, it is difficult to measure the thickness of the in-situ ultra-thin porous $\mathrm{P}(\mathrm{VDF}-\mathrm{HFP})$ membranes on $\mathrm{TiO}_{2}$ electrodes directly. For the measurement of thickness, these membranes were formed on the FTO glass by using one, two or four drops of P(VDF-HFP) acetone/ethanol solution on the FTO glass to obtain membranes I, II and III as described above. The thicknesses of the above membranes were measured using an optical microscope (Keyence VK-8510) under a magnification of 2000. I-V characteristics of the cells at AM $1.5\left(1000 \mathrm{~W} \mathrm{~m}^{-2}\right)$ were measured with a calibrated JASCO CEP-25 BX solar cell evaluation system. The solar simulator lamp was calibrated with an Eko-LS-100 spectroradiometer and a standard silicon diode. The voltage sweeping time was $20 \mathrm{mV} / \mathrm{s}$ and the scanning range was from $-0.2 \mathrm{~V}-0.8 \mathrm{~V}$. The area of the cell exposed to light was $0.25 \mathrm{~cm}^{2}$.

\section{Results and discussion}


3.1. Morphology of the in-situ ultra-thin porous $\mathrm{P}(\mathrm{VDF}-\mathrm{HFP})$ membranes

Fig. 1 (a) shows the SEM micrographs of $\mathrm{TiO}_{2}$ electrode coated with $\mathrm{Ru}$ N-719 dye, while (b), (c) and (d) show the SEM micrographs of membranes I-III covered on the $\mathrm{TiO}_{2}$ electrodes coated with $\mathrm{Ru}$ N-719 dye, respectively. $\mathrm{TiO}_{2}$ electrode coated with $\mathrm{Ru}$ N-719 dye is composed of nanosized $\mathrm{TiO}_{2}$ particles and the surface is rough. Membranes I-III cover the $\mathrm{TiO}_{2}$ electrodes uniformly and their surfaces are much smoother than that of bare $\mathrm{TiO}_{2}$ electrode coated with dye. With the increase of the membrane thickness (Table 1), the roughness of the membrane was reduced, while the number of pores was decreased.

\subsection{Photocurrent characteristics}

Fig. 2 shows I-V characteristics of $\mathrm{TiO}_{2}$ DSCs employing liquid electrolyte and insitu ultra-thin porous $\mathrm{P}(\mathrm{VDF}-\mathrm{HFP})$ membrane electrolytes under AM 1.5 radiation $\left(1000 \mathrm{~W} \mathrm{~m}^{-2}\right)$, and $\mathrm{I}-\mathrm{V}$ parameters of cells with varying thicknesses of the membrane electrolytes are summarized in Table 1. Compared to a DSC with the standard liquid electrolyte, DSCs with in-situ ultra-thin porous $\mathrm{P}(\mathrm{VDF}-\mathrm{HFP})$ membrane electrolytes have higher $\mathrm{V}_{\mathrm{oc}}$ values. This is probably related to the suppression of charge recombination at the interface between the electrolyte and the $\mathrm{TiO}_{2}$ surface.

In a DSC, the dye absorbs the solar radiation and then injects its electron into the conduction band of the $\mathrm{TiO}_{2}$ semiconductor. In $\mathrm{TiO}_{2}$ particles, there are many trap states and some of these are $\mathrm{Ti}$ (III) states resulting from the localization of an electron in the $\mathrm{Ti}$ $3 \mathrm{~d}$ orbital in the presence of an electron donating defect (oxygen vacancies, surface 
binding and intercalation of cations, proton insertion). Electrons trapped by these states leave traps by thermal activation to the conduction band and then diffuse in the conduction band until they are trapped again. When an electron reaches a trap adjacent to an adsorbed cation, recombination takes place [19-21].

Because the $\mathrm{TiO}_{2}$ can be considered as a Lewis acid and P(VDF-HFP) containing the fluoride chains as a Lewis base, Lewis acid-Lewis base interactions can exist between the $\mathrm{TiO}_{2}$ surface and $\mathrm{P}(\mathrm{VDF}-\mathrm{HFP})$ chains. When the in-situ ultra-thin $\mathrm{P}(\mathrm{VDF}-\mathrm{HFP})$ membrane electrolyte is formed on a $\mathrm{TiO}_{2}$ electrode, the surface of $\mathrm{TiO}_{2}$ electrode gets covered with the P(VDF-HFP) chains, which could cover the trap states of the $\mathrm{TiO}_{2}$ electrode. This increases the physical separation of the cation from the electrode surface and/or changes the reaction energetics and thus reduces the recombination rate [17]. With the increasing of the thickness of in-situ ultra-thin porous $\mathrm{P}(\mathrm{VDF}-\mathrm{HFP})$ membrane from membrane $\mathrm{I}$ to membrane III, the $\mathrm{V}_{\mathrm{oc}}$ values did not increase, which indicated that a very thin layer of $\mathrm{P}(\mathrm{VDF}-\mathrm{HFP})$ copolymer is enough to cover the trap states of the $\mathrm{TiO}_{2}$ particle network. Furthermore a very thin layer of $\mathrm{P}(\mathrm{VDF}-\mathrm{HFP})$ copolymer is effective to retard the evaporation of liquid electrolyte, which can improve the long term stability of the DSCs.

The lower $\mathrm{J}_{\mathrm{sc}}$ of DSC with in-situ ultra-thin porous $\mathrm{P}(\mathrm{VDF}-\mathrm{HFP})$ membrane electrolyte is due to the increased resistance to ionic conduction compared to that of liquid electrolyte. With increasing thickness of the P(VDF-HFP) membrane, the $\mathrm{J}_{\mathrm{sc}}$ values of DSC with membrane electrolyte tend to decrease, which is due to the increase 
in resistance to ionic conduction. The higher FF observed with the in-situ ultra-thin porous $\mathrm{P}(\mathrm{VDF}-\mathrm{HFP})$ membrane electrolyte is due to the suppression of the charge recombination at high voltages. With the decrease of the $\mathrm{P}(\mathrm{VDF}-\mathrm{HFP})$ membrane thickness, the efficiency of DSC with membrane electrolyte was found to increase. DSC with membrane I electrolyte showed the highest efficiency. As compared with the cell using liquid electrolyte, the $\mathrm{V}_{\mathrm{oc}}$, FF and $\eta$ of the solar cell using the membrane electrolyte increased by about $5.8 \%, 2.2 \%$ and $5.7 \%$, respectively. However, the $\mathrm{J}_{\mathrm{sc}}$ decreased by about $2.1 \%$.

\section{Conclusion}

DSCs with in-situ ultra-thin porous $\mathrm{P}(\mathrm{VDF}-\mathrm{HFP})$ membranes showed higher $\mathrm{V}_{\text {oc }}$ compared with that of DSC with liquid electrolyte. The higher $\mathrm{V}_{\mathrm{oc}}$ is due to the suppression of charge recombination at the interface between the electrolyte and the $\mathrm{TiO}_{2}$ surface. A very thin layer $(150 \pm 50 \mathrm{~nm})$ of $\mathrm{P}(\mathrm{VDF}-\mathrm{HFP})$ copolymer is enough to cover the trap states of the $\mathrm{TiO}_{2}$ electrode and increase the physical separation of the cation from the electrode surface and/or change the reaction energetics and thus reduce the recombination rate. Furthermore, a very thin layer of P(VDF-HFP) copolymer is effective to retard the evaporation of liquid electrolyte, which can improve the stability of the DSCs. DSC with the membrane I electrolyte exhibited the highest efficiency of $8.35 \%$.

\section{Acknowledgments}


Financial support from Innovative Joint Research Center, Shizuoka University is gratefully acknowledged. Authors wish to thank Dr. G. R. A. Kumara, Department of Material Science and Technology, Shizuoka University for a discussion on $\mathrm{TiO}_{2}$ electrodes.

\section{References}

[1] B. O'Regan, M. Grätzel, A low-cost, high efficiency solar cell based on dyesensitized colloid $\mathrm{TiO}_{2}$ films, Nature 353 (1991) 737-740.

[2] M. K. Nazeeruddin, A. Kay, Rodicio, R. Humpbry-Baker, E. Miiller, P. Liska, N. Vlachopoulos, M. Grätzel, Conversion of light to electricity by $c i s-\mathrm{X}_{2} \mathrm{Bis}$ ( $2,2^{\prime}$ bipyridyl-4, $4^{\prime}$-dicarboxylate) ruthenium( II) charge-transfer sensitizers $\left(\mathrm{X}=\mathrm{Cl}^{-}\right.$, $\mathrm{Br}^{-}, \mathrm{I}^{-}, \mathrm{CN}^{-}$, and $\mathrm{SCN}^{-}$) on nanocrystalline $\mathrm{TiO}_{2}$ electrodes, J. Am. Chem. Soc 115 (1993) 6382-6390.

[3] Z.-S. Wang, H. Kawauchi, T. Kashima, H. Arakawa, Significant influence of $\mathrm{TiO}_{2}$ photoelectrode morphology on the energy conversion efficiency of N719 dyesensitized solar cell, Coord. Chem. Rev. 248 (2004) 1381-1389.

[4] M. K. Nazeeruddin, F. D. Angelis, S. Fantacci, A. Selloni, G. Viscardi, P. Liska, S. Ito, B. Takeru, M. Grätzel, Combined experimental and DFT-TDDFT computational study of photoelectrochemical cell ruthenium sensitizers, J. Am. Chem. Soc. 127 (2005) 16835-16847.

[5] B. Li, L. Wang, B. Kang, P. Wang, Y. Qiu, Review of recent progress in solid-state dye-sensitized solar cells, Sol. Energy Mater. Sol. Cells 90 (2006) 549-573. 
[6] Y. Saito, N. Fukuri, R. Senadeera, T. Kitamura, Y. Wada, S. Yanagida, Solid state dye sensitized solar cells using in situ polymerized PEDOTs as hole conductor, Electrochem. Commun. 6 (2004) 71-74.

[7] G. R. R. A. Kumara, A. Konno, G. K. R. Senadeera, P. V. V. Jayaweera, D. B. R. A. D. Silva, K. Tennakone, Dye-sensitized solar cell with the hole collector p-CuSCN deposited from a solution in n-propyl sulphide, Sol. Energy Mater. Sol. Cells 69 (2001) 195-199.

[8] O. A. Ileperuma, M. A. K. L. Dissanayake, S. Somasundaram, Dye-sensitised photoelectrochemical solar cells with polyacrylonitrile based solid polymer electrolytes, Electrochimica Acta 47 (2002) 2801-2807.

[9] R. Komiya, L. Han, R. Yamanaka, A. Islam, T. Mitate, Highly efficient quasi-solid state dye-sensitized solar cell with ion conducting polymer electrolyte, J. Photochem. Photobiol. A: Chem. 164 (2004) 123-127.

[10] K. Murakoshi, R. Kogure, Y. Wada, S. Yanagida, Fabrication of solid-state dyesensitized $\mathrm{TiO}_{2}$ solar cells combined with polypyrrole, Sol. Energy Mater. Sol. Cells $55(1998) 113-125$.

[11] P. Wang, S. M. Zakeeruddin, P. Comte, I. Exnar, M. Grätzel, Gelation of ionic liquidbased electrolytes with silica nanoparticles for quasi-solid-state dye-sensitized solar cells, J. Am. Chem. Soc. 125 (2003) 1166-1167.

[12] W. Kubo, T. Kitamura, K. Hanabusa, Y. Wada, S. Yanagida, Quasi-solid-state dyesensitized solar cells using room temperature molten salts and a low molecular 
weight gelator, Chem. Commun. 4 (2002) 374-375.

[13] Z. Huo, S. Dai, K. Wang, F. Kong, C. Zhang, X. Pan, X. Fang, Nanocomposite gel electrolyte with large enhanced charge transport properties of an $\mathrm{I}_{3}^{-/ \mathrm{I}^{-}}$redox couple for quasi-solid-state dye-sensitized solar cells, Sol. Energy Mater. Sol. Cells 91 (2007) 1959-1965.

[14] H. Yang, O. A. Ileperuma1, M. Shimomura1, K. Murakami, PVDF-HFP/TiO 2 composite membrane electrolytes for dye-sensitized solar cells, in: 17th International Photovoltaic Science and Engineering Conference (PVSEC-17), 3-7 December 2007, Fukuoka, Japan, Technical Digest, 4O-A5-02, pp.146-147.

[15] A. Magistris, E. Quartarone, P. Mustarelli, Y. Saito, H. Kataoka, PVDF-based porous polymer electrolytes for lithium batteries, Solid State Ionics 152-153 (2002) 347354.

[16] W. Pu, X. He, L. Wang, C. Jiang, C. Wan, Preparation of PVDF-HFP microporous membrane for Li-ion batteries by phase inversion, J. Membr. Sci. 272 (2006) 11-14.

[17] B. A. Gregg, F. Pichot, S. Ferrere, C. L. Fields, Interfacial recombination process in dye-sensitized solar cells and methods to passivate the interfaces, J. Phys. Chem. B. 105 (2002) 1422-1429.

[18] G. R. A. Kumara, S. Kaneko, A. Konno, M. Okuya, K. Murakami, B. Onwonaagyeman1 and K. Tennakone, Large area dye-sensitized solar cells: material Aspects of fabrication, Prog. Photovolt: Res. Appl. 14 (2006) 643-651.

[19] R. Katoh, A. Furube, A. V. Barzykin, H. Arakawa, M. Tachiya, Kinetics and 
mechanism of electron injection and charge recombination in dye-sensitized nanocrystalline semiconductors, Coord. Chem. Rev. 248 (2004) 1195-1213.

[20] T. Yoshihara, R. Katoh, A. Furube, Y. Tamaki, M. Murai, K. Hara, S. Murata, H. Arakawa, M. Tachiya, Identification of reactive species in photoexcited nanocrystalline $\mathrm{TiO}_{2}$ films by wide-wavelength-range $(400-2500 \mathrm{~nm})$ transient absorption spectroscopy, J. Phys. Chem. B 108 (2004) 3817-3823.

[21] A. J. Frank, N. Kopidakis, J. Lagemaat, Electrons in nanostructured $\mathrm{TiO}_{2}$ solar cells: transport, recombination and photovoltaic properties, Coord. Chem. Rev. 248 (2004) $1165-1179$. 


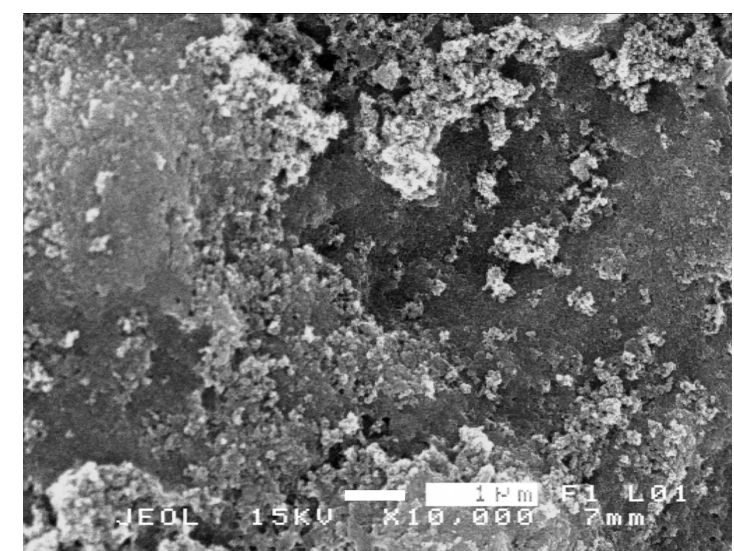

(a)

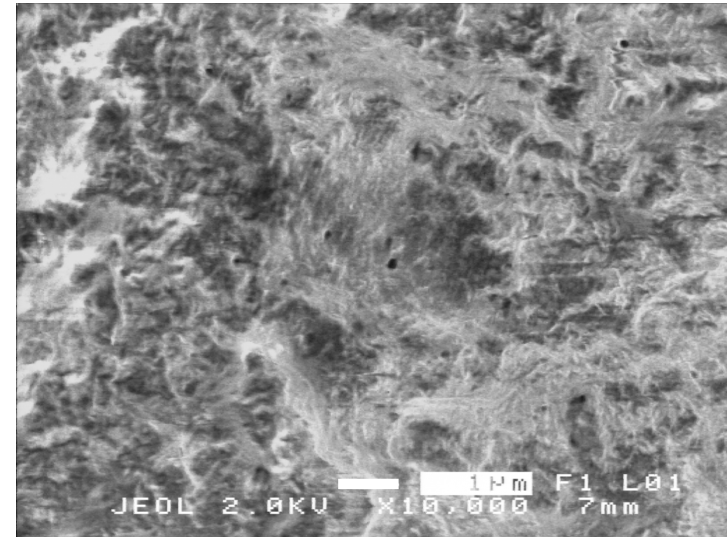

(c)

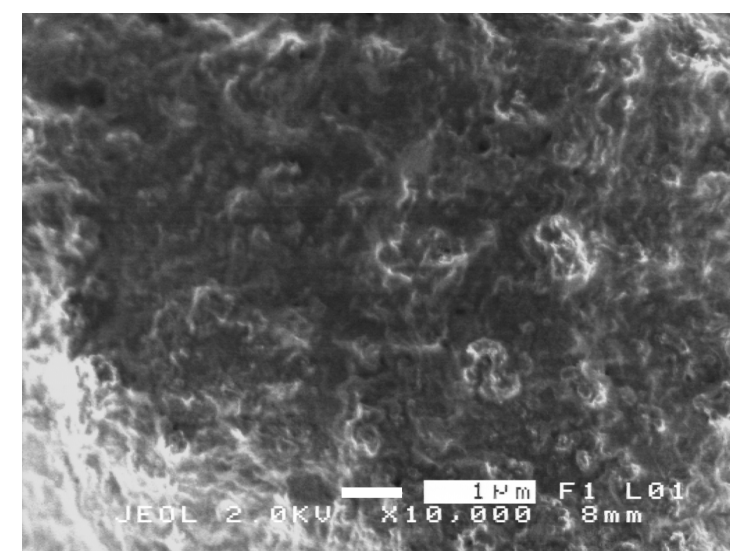

(b)

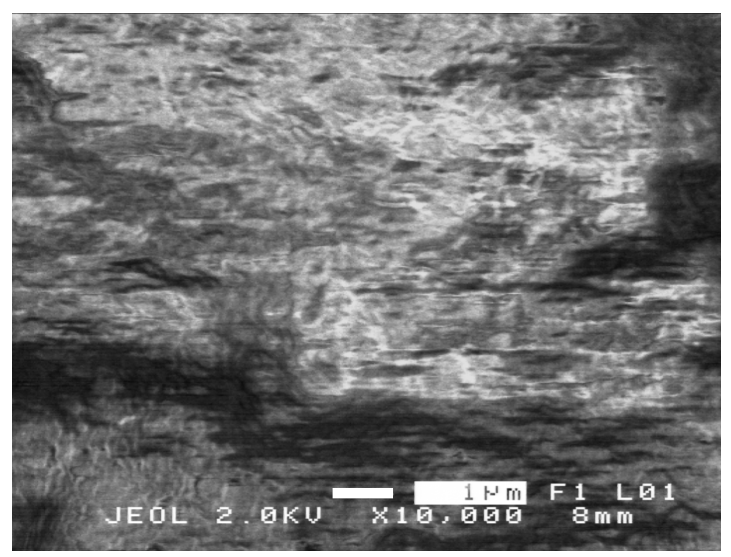

(d)

Fig. 1. SEM micrograph of (a) (No membrane) the $\mathrm{TiO}_{2}$ plate coated with dye and insitu ultra-thin porous $\mathrm{P}(\mathrm{VDF}-\mathrm{HFP})$ membranes prepared by using (b) (Membrane I) one drop, (c) (Membrane II) two drops and (d) (Membrane III) four drops of $0.4 \mathrm{wt} \%$ $\mathrm{P}(\mathrm{VDF}-\mathrm{HFP})$ acetone/ethanol solution on $\mathrm{TiO}_{2}$ plate coated with dye. The scale bar is 1 $\mu \mathrm{m}$. 


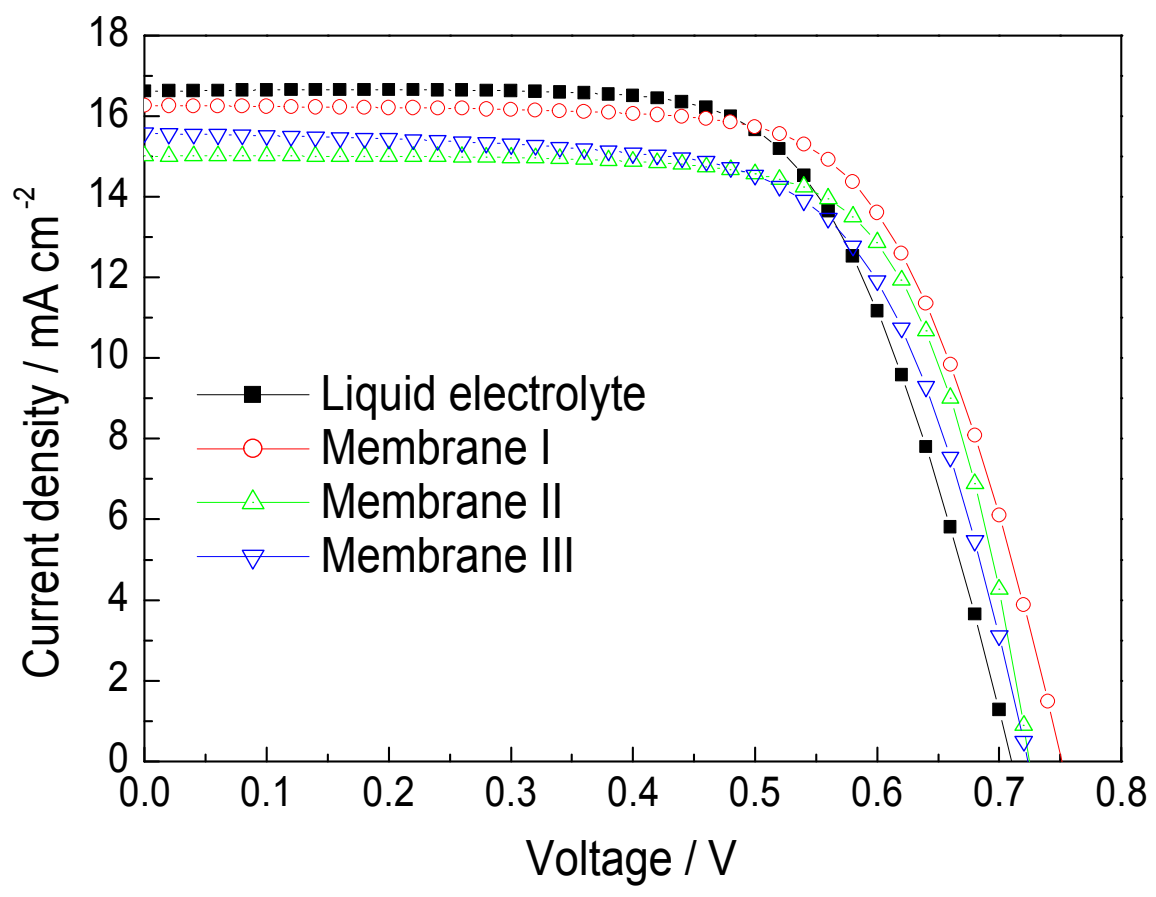

Fig. 2. Photocurrent-voltage curves obtained for $\mathrm{TiO}_{2}$ DSCs employing liquid electrolyte and in-situ ultra-thin porous $\mathrm{P}(\mathrm{VDF}-\mathrm{HFP})$ membrane electrolytes under AM 1.5 radiation $\left(1000 \mathrm{~W} \mathrm{~m}^{-2}\right)$. The liquid electrolyte had the following composition: $0.1 \mathrm{M}$ LiI, 0.05 $\mathrm{M} \mathrm{I}_{2}, 0.5 \mathrm{M}$ tert-butyl pyridine, $0.6 \mathrm{M}$ 1,2-dimethyl, 3-propylimida- zolium iodide in acetonitrile. 
Table 1

Photovoltaic performance of $\mathrm{TiO}_{2}$ DSCs employing liquid electrolyte and in-situ ultrathin porous $\mathrm{P}(\mathrm{VDF}-\mathrm{HFP})$ membrane electrolytes with different thicknesses of the membranes under AM 1.5 radiation $\left(1000 \mathrm{~W} \mathrm{~m}^{-2}\right)$. The liquid electrolyte had the following composition: 0.1 M LiI, 0.05 $\mathrm{M} \mathrm{I}_{2}, 0.5 \mathrm{M}$ tert-butyl pyridine, $0.6 \mathrm{M} \mathrm{1,2-}$ dimethyl, 3-propylimida- zolium iodide in acetonitrile.

\begin{tabular}{cccccc}
\hline & $\mathrm{V}_{\mathrm{oc}}(\mathrm{V})$ & $\mathrm{J}_{\mathrm{sc}}\left(\mathrm{mA} \mathrm{cm}^{-2}\right)$ & $\mathrm{FF}$ & $\eta(\%)$ & Thickness (nm) \\
\hline Liquid & 0.710 & 16.612 & 0.669 & 7.90 & \\
Membrane I & 0.751 & 16.260 & 0.684 & 8.35 & $150 \pm 50$ \\
Membrane II & 0.725 & 15.006 & 0.720 & 7.83 & $350 \pm 50$ \\
Membrane III & 0.723 & 15.580 & 0.669 & 7.54 & $650 \pm 50$
\end{tabular}

